Research Article

\title{
Production economics and resource use efficiency of tomato under open field condition in Kapilvastu, Nepal
}

\author{
Manoj Subedi*1 ${ }^{1}$, Madhav Pandey ${ }^{1}$, Rakesh Kumar Ojha ${ }^{2}$ and Bibek Acharya ${ }^{3}$ \\ ${ }^{1}$ Agriculture and Forestry University (AFU), Rampur, Chitwan, Nepal \\ ${ }^{2}$ Ministry of Agriculture and Livestock Development, Prime Minister Agriculture Modernization \\ Project, Project Implementation Unit, Vegetable Zone, Kapilvastu, Nepal \\ ${ }^{3}$ Former District Technical Coordinator at UN Food and Agriculture Organization, Kapilvastu, Nepal \\ *Correspondence: manojsubedi987@ gmail.com; ORCID: https://orcid.org/0000-0002-2202-5722 \\ Received: June 17, 2019; Accepted: October 28, 2019; Published: January 07, 2020
}

(C) Copyright: Subedi et al. (2020).

\begin{abstract}
(c) (1) (8)
International License.
\end{abstract}

\begin{abstract}
A study was conducted in Kapilvastu district with an objective to analyze the production economics and resource use efficiency of tomato production under open field condition. Altogether ninety tomato growers were purposely selected for household survey. Primary data were collected using pre-tested interviews and focus group discussion with tomato farmers and stakeholders. Data was analyzed using SPSS and STATA, and socio-demographic characteristics, Cobb-Douglas production function and resource use efficiency of the tomato farmers was studied. The tomato production in the studied site was found to be a labor-intensive venture as cost incurred for labor was about 39 percent of the total cost with gross margin of NRs. 7255.10 per kattha and net profit of NRs. 5464.1 per kattha. Cobb-Douglas production function analysis showed positive and significant relationship of cost on labor, seed, farm yard manure, inorganic fertilizer and micronutrients and other associated expenses with the gross income. The returns to scale of 1.02 indicated increasing returns to scale whereas resource use efficiency values indicated all input resources were underutilized in tomato production.
\end{abstract}

Keywords: Cobb-douglas production function, resource use efficiency, tomato

Correct citation: Subedi, M., Pandey, M., Ojha, R.K., \& Acharya, B. (2020). Production economics and resource use efficiency of tomato under open field condition in Kapilvastu, Nepal. Journal of Agriculture and Natural Resources, 3(1), 282-289. DOI: https://doi.org/10.3126/janr.v3i1.27181 
Journal of Agriculture and Natural Resources (2020) 3(1): 282-289

ISSN: 2661-6270 (Print), ISSN: 2661-6289 (Online)

DOI: https://doi.org/10.3126/janr.v3i1.27181

\section{INTRODUCTION}

Tomato (Solanum lycopersicum L.) is among the most widely cultivated and extensively consumed horticultural crops around the globe. In our country, tomato sits in third position after cauliflower and cabbage in terms of production area and production with 21,389 ha area and 400,674 tons of production (MOALD, 2018). Although the Terai region produces and sells more vegetables, vegetables grown in the hilly region have greater value; these vegetables are produced during the rainy season when prices are higher (NEAT, 2011). In the Hills, tomato production peaks in summer (from May to September) when it is off-season in Terai. So, only one winter season is allowed to produce tomato in open field condition in Terai.

Similarly, as per the price of tomato at Kalimati market, average prices are highest during August when there is almost no open field production and lowest during March when major supply comes from open field cultivated in Terai (KFVMDB, 2074). Hence, above statements suggests that tomato growers under open field condition in Terai are in disadvantage due to seasonal restrictions, lower product value, market constraints and several underlying production problems. Shrestha, Huang \& Pradhan (2015) stated that the major concern in Nepalese vegetable farming is limited resources available with the farmers, and inappropriate and inefficient use of these resources which has led to chronic inefficiency in vegetable production. Resources such as seed, chemical inputs and organic manure were found underutilized in sustainable soil management-based cauliflower in Dhading (Ghimire \& Dhakal, 2014). It is thus felt necessary to analyze actual production costs and whether the inputs have been efficiently utilized which can finally put light on actual economic situation of the tomato growers under open field condition in terai.

\section{MATERIALS AND METHODS}

\section{Study site, sampling and data analysis}

Two municipalities and one rural municipality of Kapilvastu district viz. Budhhabhumi Municipality, Kapilvastu Municipality and Mayadevi Rural Municipality, were purposefully selected as the study site. These sites were among the major tomato production areas of Kapilvastu district and within the working area of the Prime Minister Agriculture Modernization Project (PMAMP), Project Implementation Unit (PIU), Vegetable zone, Kapilvastu. Altogether 90 tomato growers were selected randomly for household survey - forty each from both municipalities and ten from rural municipality. Pre-tested and semi structured interview schedule was used as a tool to collect data through household survey. Similarly, focus group discussion and key informant interview was conducted; secondary data was acquired from different sources. Data thus obtained were analyzed through computer software packages like the Statistical Package for Social Science (SPSS) v.25, Microsoft Excel and STATA v.12.

\section{Costs and profit analysis}

Total cost of tomato production was computed as the sum of all the variable and fixed costs incurred during a production period. Similarly, gross margin, net profit and benefit cost ratio was computed along with return to scale to assess the profitability. 
Journal of Agriculture and Natural Resources (2020) 3(1): 282-289

ISSN: 2661-6270 (Print), ISSN: 2661-6289 (Online)

DOI: https://doi.org/10.3126/janr.v3i1.27181

\section{Production function analysis}

The following form and method of Cobb- Douglas production function was used as mentioned by Rahman and Rawal (2003) in order to determine the contribution of variable costs to gross income of tomato production.

$\mathrm{Y}=\mathrm{aX}_{1}^{\mathrm{b} 1} \mathrm{X}_{2}^{\mathrm{b} 2} \mathrm{X}_{3}^{\mathrm{b} 3} \mathrm{X}_{4}^{\mathrm{b} 4} \mathrm{e}^{\mathrm{u}}$

Where,

$\mathrm{Y}=$ Gross Income (NRs. /kattha) $\left(1\right.$ kattha $\left.=333.33 \mathrm{~m}^{2}\right)$

$\mathrm{X}_{1}=$ Labor cost (NRs. $/$ kattha)

$\mathrm{X}_{2}=$ Expenditure on FYM, fertilizer and micronutrients (NRs. /kattha)

$\mathrm{X}_{3}=$ Cost of seed (NRs. /kattha)

$\mathrm{X}_{4}=$ other expenses incurred like tillage, plant protection, irrigation, etc (NRs. /kattha)

$\mathrm{u}=$ Random disturbance term

$b_{1} \ldots b_{4}$ are the coefficient to be estimated.

The Cobb- Douglas production function in the form expressed above was linearized into a logarithmic function for ease of computation.

For the calculation of return to scale from tomato, Cobb-Douglas production function was used and calculated using formula:

$\mathrm{RTS}=\sum \mathrm{b}_{\mathrm{i}}$

Where,

$b_{i}=$ regression coefficient of $i^{\text {th }}$ variables.

The sum of $b_{i}$ from the Cobb-Douglas production function indicates the nature of return to scale.

Return to scale decision rule:

RTS $<1$ : Decreasing return to scale,

RTS $=1$ : Constant return to scale,

RTS >1: Increasing return to scale.

\section{Resource use efficiency}

The efficiency of resource use in production of tomato was determined by the ratio of Marginal Value Product (MVP) to Marginal Factor Cost (MFC) of variable inputs based on the estimated regression coefficients. The coefficients from Cobb-Douglas production are used in the resource use efficiency measurement (Naqvi \& Ashfaq, 2013). So, efficiency of the resource was calculated by using formula:

$\mathrm{r}=\mathrm{MVP} / \mathrm{MFC}$

Where,

$\mathrm{r}=$ Efficiency ratio

MVP = Marginal value product of a variable input,

MFC $=$ Marginal factor cost (Price per unit input)

The value of MVP was estimated using the regression coefficient of each input and the price of the output.

MVP $=$ MPP $x_{i} \times$ Py $($ Unit price of output $)$

But,$$
\mathrm{MPPx}_{\mathrm{i}}=\mathrm{b}_{\mathrm{i}} *\left(\mathrm{Y} / \overline{\mathrm{x}}_{\mathrm{i}}\right)
$$

Where; bi= Estimated regression coefficient of input $X_{\mathrm{i}}$ 
Journal of Agriculture and Natural Resources (2020) 3(1): 282-289

ISSN: 2661-6270 (Print), ISSN: 2661-6289 (Online)

DOI: https://doi.org/10.3126/janr.v3i1.27181

$\bar{Y}=$ Geometric mean value of output

$\overline{X_{i}}=$ Geometric mean value of input being considered

The prevailing market price of input was used as the Marginal Factor Cost (MFC).

$\mathrm{MFC}=\mathrm{Px}_{\mathrm{i}}$

Where,

$\mathrm{Px}_{\mathrm{i}}=$ Unit price of input $\mathrm{x}_{\mathrm{i}}$.

The decision rule for the efficiency analysis was as:

$\mathrm{r}=1$; Efficient use of a resource

$\mathrm{r}>1$; Underutilization of a resource

$\mathrm{r}<1$; Overutilization of a resource

\section{RESULTS AND DISCUSSION}

\section{Socio-demographic characteristics}

As inferred from the table 1, the average family size was higher than the district average 6.26 (CBS, 2012) with majority of household being male headed. Literacy rate of the sampled population was closer to the district average of 54.9 percent and dependency ratio was 0.65 . Almost all stated agriculture as their major source of income. Similarly, about 67 percent were involved in group and cooperatives while 42 percent had received some sorts of training on vegetable production.

\section{Table 1. Socio-demographic characteristics of the sampled household}

\begin{tabular}{|c|c|c|c|}
\hline Socio-demographic characteristics & Value & Socio-demographic characteristics & Value \\
\hline Mean age of respondent(yrs) & 43.73 & Male headed household & $86(95.60)$ \\
\hline Mean age of household head (yrs) & 51.90 & Literacy rate of sampled population & 466 (50.93) \\
\hline Population distribution & & Religion & \\
\hline Male & $477(52.13)$ & Hindu & 73 (81.10) \\
\hline Female & $438(47.87)$ & Muslim & $17(18.90)$ \\
\hline Average family size & 10.17 & Land holding (in kattha) & \\
\hline Age distribution & & Total owned land & 29.15 \\
\hline Active population (16-59 yrs) & $554(60.55)$ & Leased in land & 10.57 \\
\hline Dependent population & $361(39.45)$ & Area under tomato & 3.25 \\
\hline Dependency ratio & 0.65 & Institutional characteristics & \\
\hline Family type & & Member of group/cooperatives & $60(66.67)$ \\
\hline Nuclear & $49(54.44)$ & Training on vegetable production & $38(42.20)$ \\
\hline Joint & $41(44.66)$ & Organizational support & $37(41.10)$ \\
\hline
\end{tabular}

Figures in parentheses indicate percentage

\section{Economic analysis of tomato production}

Tomato production requires majority of labor in harvesting and manures and chemical application. The mean labor use in harvesting was found to be 3.16, manures and chemical application was found 2.56 per kattha (Table 2). Labor for harvesting contributes about 27.77 percentage of total labor requirement followed by manure and chemical application which contribute 22.47 percentages. Thus, the total mean labor required for tomato production in a season was 11.41 per kattha with standard deviation of 3.54.

Higher labor share for harvesting can be backed with the fact that harvesting fresh tomatoes is labor intensive and requires multiple picking. Kurosaki, Ohmori, Hamamoto \& Iwasaki (2014) in their study stated that longest work activity in large scale tomato production in Japan was 
Journal of Agriculture and Natural Resources (2020) 3(1): 282-289

ISSN: 2661-6270 (Print), ISSN: 2661-6289 (Online)

DOI: https://doi.org/10.3126/janr.v3i1.27181

harvesting which accounted for 31percent of annual work time. Bayramoglu, Gundogmus \& Tatlidil (2010) also found that harvesting operation accounts for 34.98 percent of total labor use in tomato production.

Table 2. Labor use in tomato production per kattha in the study area

\begin{tabular}{lcc}
\hline Labor (man days / kattha) & Mean Numbers $( \pm$ SD) & Percentage use \\
\hline Nursery raising & $0.66 \pm 0.28$ & 5.69 \\
Transplantation & $0.83 \pm 0.29$ & 7.25 \\
Manures, chemical application & $2.56 \pm 0.91$ & 22.47 \\
Land preparation \& intercultural & $1.72 \pm 0.89$ & 15.13 \\
Irrigation & $1.26 \pm 0.52$ & 11.02 \\
Weeding & $1.22 \pm 0.50$ & 10.67 \\
Harvesting & $3.16 \pm 1.13$ & 27.77 \\
\hline Total & $11.41 \pm 3.54$ & 100.00 \\
\hline
\end{tabular}

The study revealed that majority of cost incurred for human labor. The mean cost for the human labor was Rs. 6274.71 per kattha followed by cost for manures (FYM), chemical fertilizer and micronutrients which was 2965.68 per kattha. The fixed cost incurred during the production period was Rs 1791 per kattha which include land rent, interest on variable cost and tax.

Table 3. Cost on different items of tomato production per kattha in the study area

\begin{tabular}{lc}
\hline Items & Mean \\
\hline Variable costs & $6274.71(39.20)$ \\
Labor cost (Rs) & $2965.68(18.53)$ \\
Cost on FYM, fertilizer and micronutrients (Rs) & $627.14(3.92)$ \\
Cost on seed (Rs) & $2048.12(12.80)$ \\
Cost on tillage, irrigation fuel and plant protection (Rs) & $2299.03(14.36)$ \\
$\quad$ Other costs (staking, equipment, etc.) & \\
\hline Fixed costs & 924.00 \\
Interest on tomato production (Rs) & 867.00 \\
$\quad$ Land rent including tax (Rs) &
\end{tabular}

Gross margin of tomato production was calculated by deducting the total variable cost from the gross return and was found Rs.7255.1 per kattha (Table 4). By deducting the total cost from gross revenue, the net profit was calculated and found Rs.5464.1 per kattha. MRSMP (2016), in their report stated the net profit in main season tomato cultivation in open field condition of Bhaktapur was Rs. 265833.1 per hacter which accounts for Rs. 8861.1 per kattha. Similarly, SARPD (2016) had reported similar net profit of Rs. 8500 per kathha for Terai in open field condition.

Table 4. Gross margin and profit analysis of tomato production in the study area

\begin{tabular}{lc}
\hline Particulars (NRs./kattha) & Mean \\
\hline Fixed cost & 1791.00 \\
Total variable cost & 14214.75 \\
Total cost & 16005.75 \\
Total revenue & 21469.84 \\
Gross margin & 7255.10 \\
Net profit & 5464.10 \\
\hline
\end{tabular}


Journal of Agriculture and Natural Resources (2020) 3(1): 282-289

ISSN: 2661-6270 (Print), ISSN: 2661-6289 (Online)

DOI: https://doi.org/10.3126/janr.v3i1.27181

Benefit cost ratio was calculated simply as the ratio of total benefit which accounts for gross revenue to the total cost and was found to be 1.34 . The result of $\mathrm{B}: \mathrm{C}$ ratio was greater than unity which indicates that investment in tomato production was economically viable. Kafle and Shrestha (2017) found B/C ratio from the second year onward to be 1.65 from the case study of tomato cultivation in Hemja, Kaski.

\section{Factors contributing to gross revenue from tomato}

From the linearized from of Cobb Douglas Production Function, contribution of variable factors to the gross income of tomato production was computed and found that the labor cost, cost on seed, cost on FYM, fertilizer and micronutrients, and other associated cost incurred, all showed positive and significant relation with gross income. $\mathrm{R}^{2}$ of the model was 0.65 which indicates that $65 \%$ of variation in gross income was explained by the independent variables.

Table 5. Estimated coefficients and statistical analysis of Cobb-Douglas production function of tomato production in the study area

\begin{tabular}{|c|c|c|c|c|}
\hline Explanatory variables & Coefficient & Standard error & t-value & $\mathrm{p}>/ \mathrm{t} /$ \\
\hline Constant & 1.696 & 0.753 & 2.25 & 0.027 \\
\hline Labor cost $\left(X_{1}\right)$ & 0.482 & 0.108 & $4.47 * * *$ & 0.001 \\
\hline Seed cost $\left(\mathrm{X}_{2}\right)$ & 0.108 & 0.056 & $1.93 *$ & 0.057 \\
\hline $\begin{array}{l}\text { Expense on manure, fertilizer and } \\
\text { micronutrients }\left(\mathrm{X}_{3}\right)\end{array}$ & 0.191 & 0.051 & $3.76 * * *$ & 0.001 \\
\hline Other associated expenses $\left(\mathrm{X}_{4}\right)$ & 0.242 & 0.074 & $3.28 * * *$ & 0.002 \\
\hline $\mathrm{R}^{2}$ & 0.651 & & & \\
\hline Adjusted $\mathrm{R}^{2}$ & 0.632 & & & \\
\hline $\mathrm{F}$ value & 39.75 & & & \\
\hline
\end{tabular}

According to Farrel (1957), the elasticity of production which is the ratio of a percentage change in output to percentage change in input is used to calculate the return to scale which is a measure of a firm's success in producing maximum output from a set of input. Returns to scale was calculated as the sum of individual inputs elasticities. The return to scale was 1.02 which means that increase in all the inputs by a factor of one percent would increase output by 1.02 percent which is increasing return to scale. In contrast, Kunwar \& Maharjan (2019) found decreasing return to scale of 0.415 in off-season tomato production under poly-house in Okhaldhunga, Nepal.

\section{Resource use efficiency}

The individual input elasticities as obtained from Cobb-Douglas production function analysis was used for the computation of resource use efficiency. From the study, it is revealed that all the resources used were underutilized in tomato production. Resources used such as seed, hired labor, fertilizer, etc are underutilized in tomato production in Ghana (Tambo \& Gbemu, 2010) and Nigeria (Saleh, Kajidu, \& Abubakar, 2016).

Table 6. Estimated resource use efficiency of tomato production in the study area

\begin{tabular}{lcccccc}
\hline Expenses (NRs/Kattha) & GM & Coefficient & MVP & MFC & r & Efficiency \\
\hline Labor & 6038.94 & 0.482 & 1.618 & 1.00 & 1.62 & Under utilized \\
Seed & 570.34 & 0.108 & 3.795 & 1.00 & 3.80 & Under utilized \\
Manure \& fertilizers & 2568.83 & 0.191 & 1.505 & 1.00 & 1.51 & Under utilized \\
Others & 1927.99 & 0.242 & 2.507 & 1.00 & 2.51 & Under utilized \\
\hline
\end{tabular}


Journal of Agriculture and Natural Resources (2020) 3(1): 282-289

ISSN: 2661-6270 (Print), ISSN: 2661-6289 (Online)

DOI: https://doi.org/10.3126/janr.v3i1.27181

\section{CONCLUSION}

Although the productivity of tomato in the surveyed site is higher than the national average, there is still plenty of room for improvement in technical and resource allocation aspect in order to increase the productivity and maximize profitability. Labor costs, cost on seed, costs on FYM, fertilizer and micronutrients and other expenses have significant contribution on the gross income. The tomato enterprise was profitable as shown by the returns to scale analysis. The resources used in tomato production were found underutilized and proper utilization of resources is necessary.

\section{ACKNOWLEDGEMENTS}

The authors would like to acknowledge the Prime Minister Agriculture Modernization Project, Vegetable Zone, Kapilvastu and Agriculture and Forestry University (AFU), Rampur, Chitwan for the technical and financial support for this study. Authors are also grateful to all the respondent tomato farmers and stakeholders of survey site for their cooperation during this study.

\section{Authors contribution}

M.S. designed and conducted the survey, analyzed data and prepared the manuscript; M.P., R.K.O. and B.A. helped and supervised survey, data analysis and manuscript preparation.

\section{Conflict of interest}

The authors declare no conflicts of interest regarding publication of this manuscript.

\section{REFERENCES}

Bayramoglu, Z., Gundogmus, E., \& Tatlidil, F. (2010) The impact of EurepGAP requirements on farm income from greenhouse tomatoes in Turkey. African Journal of Agricultural Research, 5 (5), 348-355.

CBS. (2012). Population Census Report. Central Bureau of Statistics, Singha Durbar, Kathmandu, Nepal.

Farrell, M. J. (1957). The Measurement of Productive Efficiency, Journal of the Royal Statistical Society, Series A. 120: 253-290.

Ghimire, B., \& Dhakal, S. C. (2014). Production economics of sustainable soil managementbased cauliflower (Brassica oleracea L.Var. Botrytis) in dhading district of Nepal. American Journal of Agriculture and Forestry, 2 (4), 199-205.

Kafle, A., \& Shrestha, L. K. (2017). Economics of tomato cultivation using plastic house: a case of Hemja VDC, Kaski, Nepal. International Journal of Agriculture, Environment and Biotechnology, 2.

KFVMDB (2074). Annual Report of 2074 Kathmandu: Ministry of Agriculture \& Livestock Development, Kalimati Fruits \& Vegetables Market Development Board.

Kunwar, B. \& Maharjan, B. (2019). Economic analysis of off-season tomato production under poly-house in Okhaldhunga, Nepal. The Journal of Agriculture and Environment, 20, 67-77. Retrieved from https://www.nepjol.info/index.php/AEJ/article/view/25012

Kurosaki, H., Ohmori, H., Hamamoto, H., \& Iwasaki, Y. (2014). Work hours and yield for large scale tomato production in Japan. Acta Horticulturae 1037, 753-758.

MOALD (2018). Statistical Information on Nepalese Agriculture 2073/74. Government of Nepal, Ministry of Agriculture and Livestock Development, Agri-business Promotion \& Statistics Division, Kathmandu, Nepal. 
Journal of Agriculture and Natural Resources (2020) 3(1): 282-289

ISSN: 2661-6270 (Print), ISSN: 2661-6289 (Online)

DOI: https://doi.org/10.3126/janr.v3i1.27181

MRSMP (2016). Demand and Supply Situation of Tomato in Nepal 2015/16. Hariharbhawan, Lalitpur: Government of Nepal, Ministry of Agriculture Development, Market Research \& Statistics Research Program

Naqvi, S. \& Ashfaq, M. (2013). Technical efficiency analysis of hybrid maize production using translog model case study in district Chiniot, Punjab (Pakistan). Agricultural Sciences, 4, 536-540. Retrieved from http://dx.doi.org/10.4236/as.2013.410072.

NEAT (2011). Value chain/ market analysis of the off-season vegetable sub-sector in Nepal. Nepal Economic Agriculture, and Trade Activity (NEAT), United States Agency for International Development, General Development Office, Kathmandu, Nepal.45p. Retrieved from https://pdf.usaid.gov/pdf_docs/PA00JH37.pdf

Rahman, S. A., \& Lawal, A. B. (2003). Economic analysis of maize based cropping systems in Giwi local Government area of Kaduna state, Nigeria. Agriculture and Environment, 3(2), 139-148. Retrieved from https://eurekamag.com/research/004/115/004115607.php

Saleh, R., Kajidu, Y. B., \& Abubakar, I. M. (2016). Resource use efficiency in tomato production in semi-arid zone of Nigeria. International Journal of Trend in Research and Development, 3(3), 554-558.

SARPD (2016). Srijana Hybrid Tomato: A Potential Technology for Enterprise Development in Nepal.NARC, Socioeconomics \& Agricultural Research Policy Division, NARC, Khumaltar, Lalitpur, Nepal,

Shrestha, R., Huang, W., \& Pradhan, U. (2015). Resource use efficiency in vegetable production in the high hills of eastern Nepal. Nepalese Journal of Agricultural Economics, 2-3, 79-87.

Tambo, J. A., \& Gbemu, T. (2010). Resource-use efficiency in tomato production in the Dangme west district, Ghana. Conference on International Research on Food Security, Natural Resource Management and Rural Development, ETH Zurich, September 14-16, 2010, Switzerland. Retrieved from https://pdfs.semanticscholar.org/1920/0d21a48be2b49c01fef1900d46648a8a141d.pdf 